Award to be awarded annually or from time to time to Canadians who have made outstanding contributions to international forestry. Four have had this honor bestowed upon them.
Recipients of the International Forestry Achievement Award

1988 R.W. Roberts

1989 M. Stewart

1990 J.H. Cayford

1991 B.S.P. Wang

D.R. Redmond, Chairman, Archival Committee

\section{International Honour for CIF Staff Member}

Los Angeles - A Canadian with an international reputation for forestry work in many parts of the world, James $\mathrm{H}$. Cayford, was presented with the American Forestry Association's Bernhard Eduard Fernow Award in recognition of his outstanding achievements in international forestry.

The award, presented November 12 in Los Angeles, was established in 1965 by joint agreement between the American Forestry Association and the German Forestry Association and has been presented to recipients from ten different nations. It is named after a
German forester who emigrated to the U.S. in 1876 and became founding head of the first professional school of forestry in the U.S. at Cornell University. Dr. Fernow later moved to Canada, where he established and became Dean of the first Faculty of Forestry in Canada at the University of Toronto in 1907.

Jim Cayford, a native of Montreal has had a remarkable career in international forestry. He was employed by Forestry Canada from 1952 to 1987 where he retired as a Director General. He served as Executive Director of the Canadian
Institute of Forestry from 1987 to 1990 and is a former President of that organization. He is currently the Editor of the Institute's professional journal, the Forestry Chronicle.

Jim Cayford has been closely involved with the International Union of Forest Research Organization (IUFRO) and provided leadership in organizing the World IUFRO Congress held in Montreal in 1990. He was recently elected Vice-President of Administration of that organization. Jim was a Chairman of the Canada-USSR Working Group on forestry and he attended and contributed to the programs of two World Forestry Congresses, one as head of the Canadian delegation. He has been active in the UN's Food and Agriculture Organization for many years, serving on the Canadian delegation in Rome, as a contributor to FAO symposia and in several capacities on the North American Forestry Commission.

Jim has planned and reviewed Canadian foreign aid programs in forestry
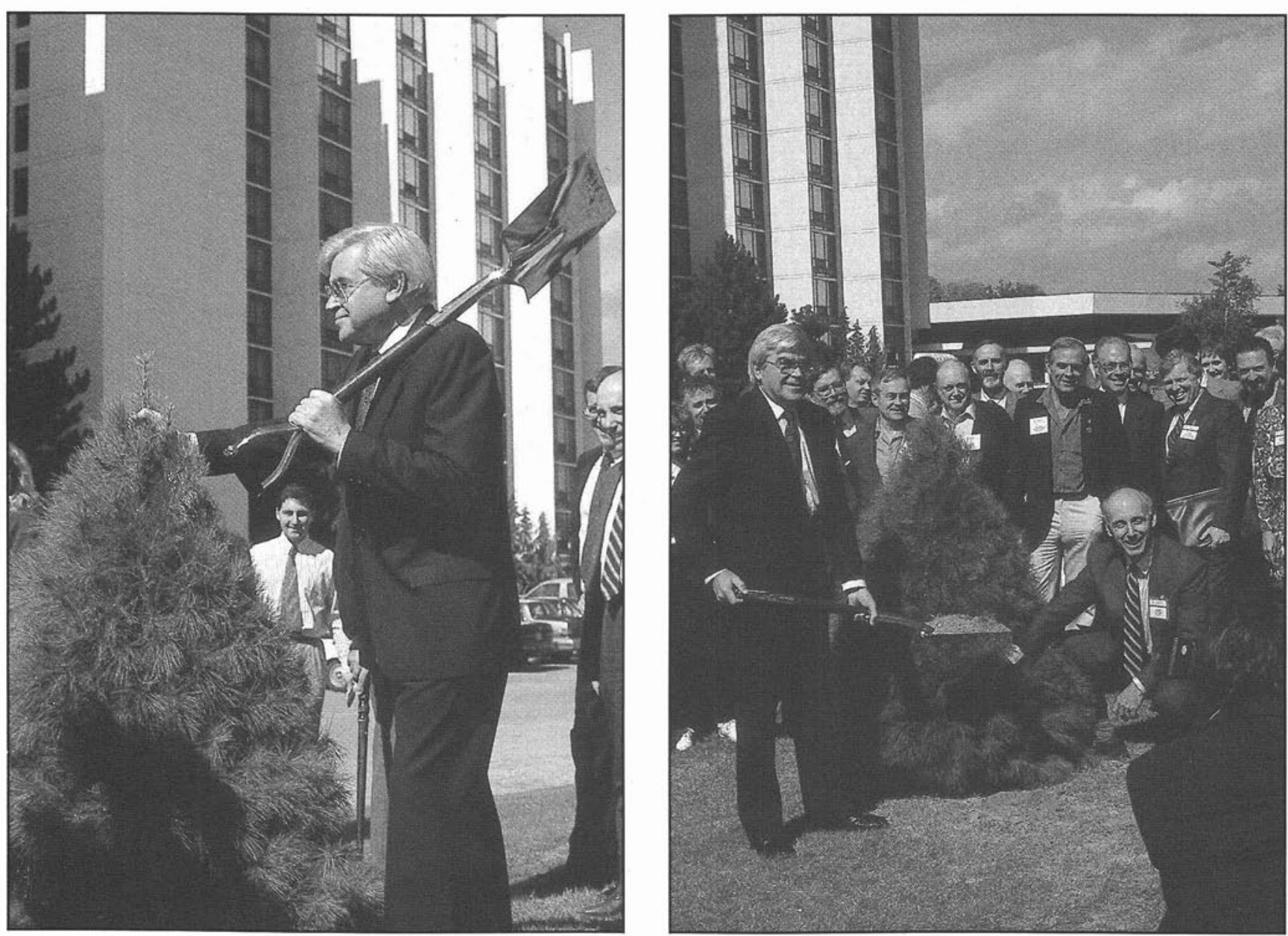

Federal Minister Frank Oberle plants tree during 1991 CIF/IFC Annual Meeting in Toronto. 
and is frequently invited to serve in bilateral activities between Canada and the U.S. He has travelled to study forestry in many countries on five continents. He was also the recipient of the
Canadian Institute of Forestry International Forestry Award in 1990.

CIF/IFC News Release

\section{Discussion Paper on Suggested Interrelationships and Various Functions of the CIF/IFC}

The Canadian Institute of Forestry/ Institut Forestier du Canada is the only national forestry association that represents professionals practising forestry across Canada and congregates some 2,500 members from one end of the country to the other.

The objectives of the CIF/IFC are clearly stated:

1. To improve all aspects of forestry in Canada.

2. To foster public understanding of forestry, forests and forest industry including their importance to the economy and their role in the maintenance and improvement of environmental quality.

3. To advance members in their knowledge of forestry.

4. To cultivate an esprit de corps among members.

5. To publish a professional and scientific forestry journal.

6 . To cooperate with other organizations having similar objectives.

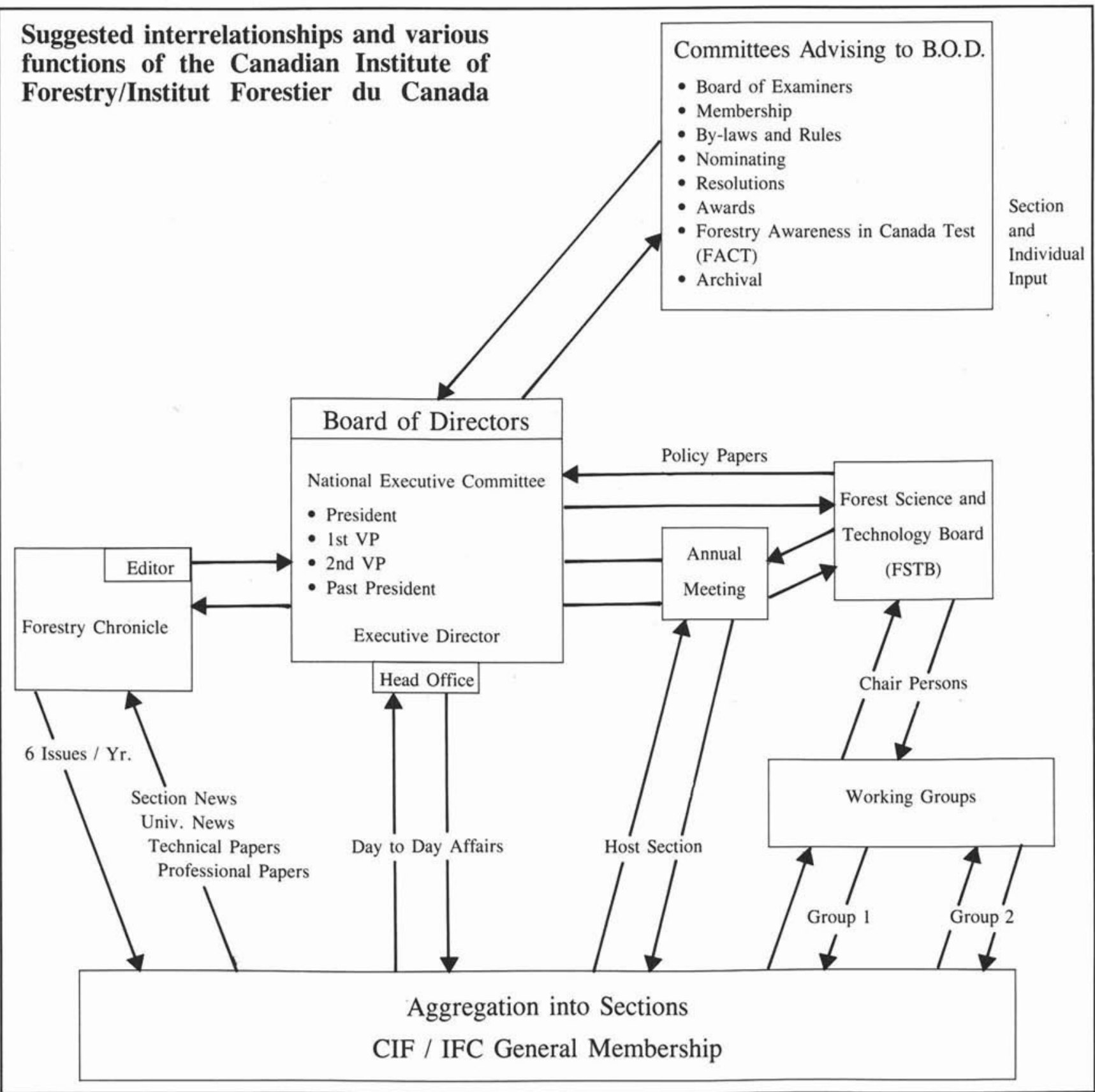

